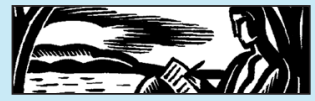

\title{
Unseen: Exploring the Lived Experience of Visually Impaired South Africans
}

\author{
Joanne Bloch
}

(Research Associate, Wits Institute of Social and Economic Research)

\section{ABSTRACT}

The liminal space occupied by partially sighted people is little understood and much misrepresented in South African societies. Inter-personally and more broadly, visually impaired South Africans face stigma, discrimination and numerous structural barriers to educational, social and economic opportunities. These challenges remain largely invisible to those who never experience them.

In this paper, I discuss my conversations with four South Africans who, like me, are visually impaired. These conversations form part of my research for Unseen, a project that brings together my interests in life writing and in exploring different aspects of the experience of visual impairment. I weave substantial extracts from our dialogues together with my own insights so as to give a sense of the texture of the participants' reported understanding, ideas, feelings, and sensorial adaptations, and also to investigate the multiple and overlapping influences of class, race, gender, age, community, sexual orientation and family on each individual's subjective experience.

Keywords: visual impairment, disability, life writing, marginality, social exclusion, stigma, embodiment, intersectionality

\section{INTRODUCTION}

My project Unseen began its long germination one afternoon in mid-2011. On that day, as his two-man backup team gazed on impassively, the chief neurosurgeon at Groote Schuur Hospital in Cape Town told me with 
brutal candour that there was absolutely nothing he could do for me-I would inevitably lose what was left of my sight.

As anyone facing such a diagnosis must, in the nine years that have passed I have undergone a prolonged, and in my case, confused and confusing re-orientation, complete with frustrating hiatuses, detours and false moves as well as a fairly recent partial reversal in the predicted trajectory of my vision. As a visual artist, it was not easy to re-imagine my creative process. Slowly, I became aware of the productive possibilities of bringing my concern with sight loss and its implications and my experience with and enthusiasm for life-writing work together. I began Unseen, my conversation-based project with visually impaired participants in early 2019 as a Research Associate of the Wits Institute of Social and Economic Research (WiSER). This paper presents my first attempts to process and consolidate my research.

The texture of disabled peoples' lived experience varies from society to society, and even within societies, depending on a range of historical, economic, cultural, political, legal and other intertwined factors. So, for example, state and organisational support to allow for access to education, transport and the built environment in one of the wealthier Western European nations is likely to be much greater than that available in the countries of Sub-Saharan Africa. It follows that generalising from one society to another can only be undertaken with extreme caution. Even so, my research in the South African context reveals issues very likely to have correspondences in other parts of the world, including Europe. According to the European Blind Union, 'blind and partially sighted Europeans are undoubtedly among the most vulnerable and least visible members of society. For the most part they are at the bottom end of the earnings league' (European Blind Union, n.d.). It is noteworthy that according to this organisation, negative attitudes and prejudice are amongst the nexus of factors leading to exclusion. Unfortunately, the disavowal and stigmatisation of disability that have existed throughout human history persists to this day across the globe.

My project has precedents amongst various life writing narratives. Most, though not all of them, are autobiographical, and came into being as an expression of new ways of conceiving of disability opened up by the burgeoning disability rights movement in the last few decades of the twentieth century (Couser, 2001: 177-79). South African examples of such personal narratives are uncommon. They are even rarer in relation to visual impairment. One exception is provided by a recent article exploring the complexities faced by disabled people in navigating a society burdened by the legacy of the apartheid system of racialised oppression (Botha and Watermeyer, 2018: 1-7). Despite a markedly progressive South African 
Constitution that honours and safeguards human rights and equality, deep divisions and disparities in power and wealth persist along racial lines, in tandem with pernicious ongoing racism. In this highly charged sociopolitical climate, the rights and needs of disabled people are easily contested, de-prioritised, distorted and misunderstood.

Botha and Watermeyer take Botha's difficult childhood experience at the Athlone School for the Blind in 1994, the year of South Africa's transition to democracy, as their starting point for exploring the complex intersections of disability, race and identity in post-apartheid South Africa. Their particular concern is the unstable subjectivity produced by being blind and White, so that the privilege of Botha's racial identity is understood to negate the marginalisation she experiences via her disability.

In conceptualising this project, I was influenced by my personal experience of sight loss and visual impairment, through which I had discovered that the terrain of partial sight, my own indeterminate space with all its variations, vacillations, compromises and adaptations, is one that is very seldom examined or even represented in the society in which I live. With this realisation in mind, I was particularly interested in engaging with others who were not born blind, but had experienced or still retained some degree of sight. Whatever emerged, I knew that visual impairment is unfamiliar terrain to most able-bodied people, and that where it is represented in the media and in the broader cultural imaginary, it is often via misleading misconceptions, from the trope of the super-human, inspirational disabled hero to a battery of downright crude and ugly stereotypes. More often than not, the embodied everyday realities of visually impaired South Africans' lives remain almost entirely hidden to our fully-sighted compatriots.

In Unseen I am using the creative and open-ended approach afforded by life writing rather than a more structured and boundaried research methodology. The project is modest in scale and ambition- rather than aiming to address the many structural challenges facing visually impaired South Africans, its ultimate objective is to promote awareness, by giving voice to those who are usually silenced. I believe that it is from such awareness that solidarity grows.

My contention is that my own compromised sight allows me, at least to some degree, to consider myself as a participant researcher rather than an observer and recorder with any claim to impartiality or greater knowledge and understanding of the issues we discuss. I have tried to signal this intention to disrupt any sense of a hierarchy in my interactions with participants by understanding and referring to them as 'conversations' and 'dialogues', rather than 'interviews'. My participation speaks to the idea that conducting research with visually impaired people as one 
experiencing similar conditions myself allows for a degree of deconstruction of the hierarchical relationship that can prevail between researcher and researched, and a sense of solidarity in the engagement. At the same time, as a middle class white South African, I cannot be unaware of the privileges automatically bestowed by my own class position and racial identity. Bearing this in mind, and with the knowledge that factors like race, class, age, gender, sexual orientation, family and community have intersecting and often compounding effects on individuals' experiences, my aim with this project is to allow a diverse cross-section of voices to be heard.

This paper concerns the work I have done with four of the project participants. I include substantial extracts from our discussions, so as to give as full a sense as possible of the texture of participants' reported experiences, ideas and feelings. I also try to draw out and expand on some of my own insights that have arisen in response to our conversations.

\section{MOGOROSI}

Mogorosi's passion for cartooning has sustained him from his earliest days in the 1960s, when he drew in the dirt outside his grandmother's house in Batho Township near Bloemfontein. He is well-connected and well-respected in South African cartooning circles. In 2016, he published The Initiation, the first volume of his graphic autobiography, 360 Degrees. He was the first Black South African to record his life experience in this way.

Mogorosi and I met many years ago. In the 1980s, he drew the cartoon Sloppy for the adult literacy magazine Learn and Teach, my own workplace for about two years. At that time I was struck by his self-contained, fineboned beauty and grace. To me, he was the epitome of township cool, drifting in and out of our chaotic offices in his white overalls. 'Heyta daar [hello there]!' he would say, as he passed my desk. I greeted him in return, but never dared to say more.

I too was a cartoonist in the 1980 s and drew and exhibited cartoons sporadically for some years in subsequent decades. A mutual cartooning friend brought Mogorosi to visit me in about 2007. Though he wasn't in good health, he was utterly dedicated to the painstaking production of his graphic memoir. The next time I heard his voice was ten years later, when quite by chance I discovered that an episode of the BBC World Service podcast, The Outlook was devoted to his graphic novel, and what it revealed of one life under apartheid. I listened eagerly, but was astounded and saddened to hear the sting in the tail of the story: recently, Mogorosi's sight had deteriorated, and he could no longer see well enough to draw. When 
I contacted him, it became clear that since the doctors he had consulted hadn't arrived at an immediate solution, he was living in a state of limbo, hoping for a medical solution, yearning to draw again, and at the same time trying to find new ways to occupy himself with extremely limited resources. Before my own severe sight loss, I had been as immersed as Mogorosi was in making visual art, so I know just how excruciating it can feel to attempt this drastic shift.

Still, there's a lot that I don't know. When I asked Mogorosi if he experienced discrimination after his disabling recent sight loss, I discovered that I was wrong to have assumed that the answer would be yes:

Mogorosi: I find people sympathised more than, you know, discriminated. They sympathised a lot.

Joanne: Really? ... All people?

Mogorosi: All the people I can think of ....

I remember I had this friend who was a shop keeper, you know, when I couldn't see, because like I would buy something like, let's say, airtime token, I would ask him to, to..

Joanne: ... put it on your phone for you?

Mogorosi: Ja [yes], and he would take the time to do it. I mean, he would tell all the other customers that, look, I'm trying to help a friend here, so could you wait. I mean, he was very sympathetic, and even people wouldn't know me, they would wait, because of that, you know.

This reply wipes away all traces of my smug conviction that as a visually impaired person myself, I will, at least in broad strokes, understand the experience of others whose sight is compromised. Mogorosi's assertion forces me to think again, to try fully to engage with how differently lives play out, depending on the complex mesh of overlapping conditions that make us who we are, and elicit responses as distinct as fingerprints. It takes a more in-depth knowledge of Mogorosi's life-story and character to begin to understand how he experienced responses to his sight loss.

As a younger man, Mogorosi lived hard. He tells me that 'When I met one guy after a long time, he said, "Wow, are you still alive? I thought you'd be dead long ago!"' His alcoholism was to take its toll, but other, unpredictable events had lasting repercussions too. In 1985, a corneal ulcer left him with minimal sight in his right eye. While a transplant was 
mooted as a possible solution, the waiting period was around ten years. Mogorosi decided to carry on living much as he had before, adapting to seeing with one eye.

Four years later, a vengeful ex-lover poured boiling water over Mogorosi's body as he slept. The skin of his chest was severely burnt, and his right eardrum burst. This left that ear deaf. Again, the possibility of surgery was mentioned, but this operation never materialised either:

'... they told me something about ... pigskin replacement, and ... like you know ... Hillbrow Hospital was turned into a clinic, and so it was never as good as it was as a hospital.'

Again, Mogorosi stoically adjusted to his new bodily conditions:

'I don't think it was anything, I mean, conscious, that I tried to do to ... you know ... I just went on with my life as it was. I had to adjust to people, you know ... I have to keep reminding them that I'm deaf in my right ear, like when we're walking along ... I have to be on the right side of whoever I'm walking with ...'

Making these daily accommodations is possible and necessary, although it can be wearisome; but Mogorosi points out that often, there's a need to go further, to make fuller explanations so as to mollify easily-slighted acquaintances, and explain, if possible, the subtleties of partial sight:

'I actually remember a guy in Bloemfontein, ... somebody I know, I just walked past him ... so he said to me, "hey! Can't you greet, you know?" I said, "look, I can't actually see you." "But ... how do you see where you are going, when you can't see me?" You know, stuff like that.'

The obligation always lies with Mogorosi, no matter how he's feeling on any particular day, to adapt to what is normal to others, and to placate them when his own unseen and misunderstood conditions cause confusion or offence.

In apartheid times, Mogorosi was an activist. After ten days of solitary confinement in Bloemfontein in 1980, he lived out the harsh, dangerous final decade of apartheid rule in Johannesburg. There he was arrested twice more for the possession of political pamphlets.

Two frames in the introduction to The Initiation illustrate his experience of the period of transition to democracy. In the first, with arms outstretched, Mogorosi contemplates a vision of Nelson Mandela's face in a bubble above the Johannesburg skyline. The caption reads, 'With the advent of democracy, I looked forward to a better life.' Yet in the 
following frame, Mandela's face has transmogrified into that of a malevolent demon. The caption here reads, 'But then this goblin reared its ugly head.'

Mogorosi explains that the advent of democracy was also the time at which he began to have many problems with his skin:

'... I had eczema, I had all kinds of rash, I had stuff, you know, and I thought it was just that. Until I went to Mofolo Hospital, that was in '96 ... so this doctor ... wanted to know if I had ever been tested for Aids. And I said, "no".'

When Mogorosi discovered he was HIV positive, he experienced the full force of rejection and stigma. He remarks, 'You know, the discrimination, you can take if it's from strangers or stuff like that, but not from your friends.'

Joanne: Did you experience that?

Mogorosi: Ja, I did ... you know, it's like they ... you walk in, and they walk out.

Joanne: As bad as that?

Mogorosi: 'That's right. If you see a group of your friends talking ... like I used to go to a place, I mean, where we had our beers and stuff, you know, you'd take a glass of beer, and drink from it, no one else will touch it; not your friend, not your stranger.'

Mogorosi points out that although the experience of discrimination hurt him, he never showed it, since '... that would give them pleasure ... So I never really showed it, just kept it in, within myself.'

This reaction is in keeping with Mogorosi's general restraint when it comes to revealing his feelings. He describes himself as a very reserved person, who has never been one to discuss his feelings openly. When I ask him if this is due to his upbringing as a male, he laughs:

\footnotetext{
'No, no, I think I've always been like that, I mean, I've never liked talking ... my brother, if he's got a problem, he'll always talk, you know ... He'll always show his emotions, ja. And I just sit back and wonder why. What is it all about ... [ ] ... you know?'
}

As well as invisible impairments and chronic illness, over the years of his adulthood Mogorosi has endured a lot. He's survived the multiple brutalities of apartheid, a vicious, painful physical attack with severe permanent 
consequences and a wall of devastating stigma from his friends when they discovered his HIV status. These experiences contextualise his subsequent understanding of the attitudes of others, including those relating to his sight loss. This is not to suggest that his family, friends and neighbours weren't genuinely kind at that time. However, it seems important to note that after being exposed to so much violence and rejection, both institutional and personal, Mogorosi has no expectations of others' behaviour. While kindness comes as a welcome bonus, he's learned how to survive if it's absent.

Of course, the oppression and cruelties Mogorosi has been exposed to are not unique to his life. They differ only in the details to the conditions experienced by most other South Africans living with chronic illness and disabilities, who have no choice but to tough it out in an unsupportive, even callous environment, in which inclusivity can never be taken for granted. These harsh difficulties could only have been amplified for Black people by the multiple oppressions of apartheid.

Mogorosi's power of resolute endurance has both facilitated and been facilitated by his focus on what has mattered most to him over many years-the dogged pursuit of his calling: drawing.

In this regard, Mogorosi is in luck. The first ophthalmologist he saw in 2017 considered that a corneal transplant was his only available solution. There are still long waiting lists for this operation as well as high risks in Mogorosi's case. These issues aside, this surgery is impossible to perform unless a longstanding herpes infection present on Mogorosi's cornea clears up-an extremely unlikely prospect in a person with a compromised immune system. Fortunately, the second ophthalmologist he saw just before our conversation in 2018 had a different perspective. Instead of surgery, she prescribed a simple, yet somehow previously overlooked measure-a pair of spectacles. Now, Mogorosi is drawing again.

'I feel like punching the air!'

He exclaimed after his visit to this doctor in an uncharacteristic display of jubilation.

Had Mogorosi not had the chance to access the second doctor, he would have had nothing to celebrate. This illustrates just how easily patients can fall through a gaping crack with little prospect of ever emerging. That this can happen even in the care of private specialists not exhausted and overstretched by the demands of our under-resourced and often dysfunctional public health care system raises unhappy questions about the uneven standards of care for visually impaired South Africans. 


\section{ALEXANDRA}

Alexandra and I have something unusual in common-we both chose to proceed with postgraduate degrees in Fine Art despite worsening sight loss.

The first time we meet, Alexandra is in the throes of completing both her MA thesis and her exhibition work. She explains that, as an undergraduate, she had more sight than she does now. Even though a drastic subsequent decline in her sight necessitated a total shift in navigating every aspect of her environment, she decided to pursue her MA in 2017. She tells me that she consciously chose art as a pathway to understanding her altered identity:

'... in all my MA work, I've tried to explore the interactions between the way I see now, my memories of seeing, the expectations I once had that now are like, obviously overturned, and my re-orientation process.'

A few years earlier, I had found myself in a similar position to the one faced by Alexandra. Six months after beginning my PhD in Fine Art, I was confronted with the prospect of intensifying sight loss. My response, like hers, was to continue with the work, in my case by pursuing experimental making processes that acknowledged and incorporated my new subjective sensorial experience. I adjusted the scale of all my work, and much of it invited access via sound, smell or touch. In contrast, Alexandra chose to continue to produce entirely visual artwork.

All resemblance between our strategies ended after I finished my $\mathrm{PhD}$. At that time, I took a conscious decision to turn my back on visual art. This was a painful prospect, but the alternative-continuing to engage with art-making as the heart of my creative life with degraded and dwindling vision-felt too compromised as well as too exhausting to countenance.

Now, meeting Alexandra, I am struck by her determination to persevere with visual production in spite of having lost around 90 percent of her sight. She explains that 'I didn't feel like turning away from drawing and painting and trying other media ... people always suggest sculpture, but it just doesn't appeal to me ... we live in a progressively more visual culture, whether my own experience has changed or not ... In any case, visuality wasn't like a switch I could just turn off and that's it. That would need to happen more slowly, more like a dimmer switch.'

For me, her commitment to her choice arouses a mixture of incredulity and admiration. Speaking to Mogorosi sparked some flicker of realisation that, although my sight is worse than his, maybe I too could still consider making artwork again. My first conversation with Alexandra does 
something more. It awakens in me a prolonged internal debate between a voice advocating for holding on and one that defends letting go-the merits of persevering with the form of creative practice I had embraced when I had more viable sight versus a complete change of direction. In my liminal seeing space, neither side ever decisively wins.

One effect of the form of ectodermal dysplasia that Alexandra was born with was that her eyes had always been too dry.

Over time, the friction of Alexandra's left eyelid rubbing against her cornea resulted in a build-up of scar tissue that pulled her eyelid closed. Painful infections and the ordeal of undergoing and recovering from annual surgeries have shaped her life. So have confounding variations in her sight, which repeatedly necessitate the evolution of new strategies to cope with new conditions, just to manage walking, dressing, or making a cup of tea. This demanding process is, of course, totally invisible from the outside.

Alexandra's medical history reveals the alarmingly contingent nature of even private medical care. She was 14 when, after another operation, her doctor went away on holiday without removing a hard contact lens from her patient's eye:

'Because my eye couldn't breathe ... the bacteria just grew ... it was such intense pain, like I can't describe it ...'

This disastrous blunder ultimately melted Alexandra's cornea. She now wears a prosthetic left eye.

In her early 20s, what was left of Alexandra's vision suddenly dipped dramatically. Again, she was unlucky. A succession of doctors prescribed medications that only worsened the problem. Her eyelids went into intense, prolonged and horribly painful spasms. After three months of lying in bed, incapacitated by pain, her doctor relieved the spasm with botox.

Alexandra contends that this measure was put into place too late to avoid the extensive, irreparable corneal scarring that has diminished her sight further. She is not a candidate for a corneal transplant.

Alexandra comes across as friendly and humorous. Her guide dog and sunglasses reference blindness, but the image they conjure is one-dimensional. Unless she chooses to speak about her tough, prolonged struggles with her sight, all that she has endured in terms of her sight loss remains hidden.

In contrast, another effect of her condition, the abnormal shape of her fingers and toes, is immediately obvious. Just as Mogorosi experienced more benign responses to his failing sight than to his highly stigmatized 
HIV status, Alexandra reports that reactions to her fingers have been far more insensitive than responses to her visual impairment.

Worse than the teasing from other small children was her grandfather's attitude:

'He made me promise to get my fingers and toes 'fixed' to look normal ... he said it wasn't good for a woman to look like I did.'

Her reaction to the pressure of being different was to hide her hands in her sleeves or turn them in a certain way. She tells me that to this day, she mostly holds her hands in a way that minimises their different appearance. Even so, she has experienced hurtful reactions:

'Obviously people can kind of rein themselves in a bit, like when we're adults ... [but if] ... suddenly someone sees, it's like this look of like absolute horror, like this abject kind of disgust ... I'm kind of glad I can't see that anymore.' She pauses, then says, 'in a way, like I don't really blame them, because I think some of it is just shock ...'

As is often the case in the interactions between disabled and able-bodied people, Alexandra takes on both the task of normalising the appearance of her hands, as well as putting herself in the shoes of others, in a bid to forgive, or at least understand, their hurtful reactions.

Alexandra lost most of her remaining sight about five years into her first relationship. She recalls that '... he sort of had to become like a parttime caretaker if we were ever to go out. I didn't know how to use my cane, at that point, so he always had to kind of like drag me along, and tell me if there were steps and ... everything, like take me to the bathroom ... it was not really the romantic stuff.'

She recognises now that she and her boyfriend were unable to communicate about the implications of what had happened:

'... we never spoke about how the dynamics changed, and how maybe like our roles in the relationship had changed, or should change, or adapt. But I don't think either of us knew how to deal with the situation ...'

This observation recalls my own experience after an operation I underwent in 2017. Although the surgery enlarged my visual field, it considerably reduced my acuity and drastically increased my difficulties with glare. Suddenly I found myself undergoing cane training. Physically tired, feeling isolated by lack of vision, shocked and disappointed, I withdrew into myself as I tried to adjust my somatic orientation. My well-meaning partner understood me to need space, which made me feel even more isolated. Sometimes, it can feel that there are no words with which to communicate. 
The painful dynamics between Alexandra and her boyfriend were compounded by unthinking but emotionally bruising responses from casual observers when they went out,

'... before they used to refer to him as my boyfriend ... [Now] ... they suddenly said, "oh, do you and your friend want a table?" And that was like the beginning .. that was one of the first kind of stabs in the heart for me, with like disability in general. Like why did I suddenly become de-sexualised? When I was in my $20 \mathrm{~s} . .$. this is the time like my body's never going to look like this again, and I feel good ...'

Desexualising assumptions, some of them intentionally hostile and offensive, are all too common in disabled people's reported experience. Their cumulative effect and an awareness of the attitudes that give rise to them can be very destructive to those on the receiving end (Apps, 2016; Das and Joseph-Salisbury, 2016; Hall, 2017). Now single, Alexandra has thought deeply about the difficulties of meeting prospective partners as a disabled person. She describes how fraught this undertaking is in an era when most dating takes place within a heartlessly throwaway consumerist online dating culture:

'... it just feels like you're selling yourself ... and a lot of that kind of marketing would be photography, and like being this perfect beautiful package, which no one is.'

When self- promotion via endless photographs trumps all other incentives to engage, those with visible disabilities can find themselves at a very real disadvantage, dismissed as inadequate or 'other' before even one word has been exchanged. Even if this hurdle is successfully negotiated, there remain very real difficulties in revealing bodily differences and particular needs to total strangers. These issues have awoken an interest in Alexandra in exploring the complex terrain that disabled young people wishing to build romantic and sexual relationships must negotiate.

\section{PAUL}

Paul tells me that he never makes an issue of his blindness.

'I don't mope ... I always make light of it, I'm always chatty and smiling about things and ... you know?'

I do know. My own experience of visual impairment has taught me that a determined positivity, or sometimes just a performance of it, is essential 
armour against pity, groundless assumptions and a host of unwanted projections. Paul's assessment of his own behaviour is reinforced by the person who introduced us to one another. He tells me that Paul never complains. I believe him - the ability to push positivity to its limits, to abjure all complaint is a quality that is, (arguably often rightly) prized as the sign of a strong character in our culture. Yet an embargo on the expression of all feelings considered to be negative ('whining', 'moaning', 'self-pity') can easily foreclose discussion of the losses, and consequent difficulties with which those feelings are bound up. If the very real differences between the physical and sensorial experiences of sighted and partially sighted people are erased, it becomes that much more difficult to disclose the discomfort of everyday corporeal experience, in the hopes that even one able-bodied confidant will have some sense of one's altered perceptual experience. With this in mind, I listen when Paul describes the way he sees:

'... liken it to a couple of ballpoint pens that you put together and just scratch ... and you get all that ... scribbling on the thing; that's what I see in the eye ... and of course, it moves ... it's sort of moving inside the eye.'

I ask him if he has ever described the way he sees to anyone close to him. He replies that he does sometimes speak to his children about his sight; but when I question him further, I understand that these interactions don't invite his family members temporarily into his sensory world. Rather, he tries, as all those who experience sight loss must do, to orientate himself into their world, the world he lost:

'... when we're in the car, and I sometimes can see a colour, you know, although it's also getting a bit.. but I will remark, was that a red car that just passed now? And they'll say, yes.'

His communications about his own experience of limited sight also take the form of reminders, as in

'... “it's dark, I can't see you," I always keep on telling him, “I can't see your face and that, but I can see light there."

The particularities of distorted and often uncomfortable sensorial experience aside, never expressing very real daily difficulties has further ramifications for Paul. His silence allows the social disadvantages of his disability to be passed over, so that both obvious and more subtle stigma, as well as structural barriers to access are invisibilised to those he lives amongst. They are free to perceive of Paul simply as an unfortunate individual, rather than as one of millions of South Africans 
marginalised and often discriminated against as a response simply to their physicality.

Paul's eye damage was caused by Type 2 diabetes, which was diagnosed in 2000. Ten years later, his sight began to suddenly and rapidly deteriorate. He underwent surgery for a detached retina in his left eye. At the routine check-up appointment three months later, his sight was good. Then something went wrong, he thought, in the pressure inside his eye. The medications he was given didn't help, and he lost all sight in that eye. At the same time, the sight in his other eye deteriorated too, evidently due to damage caused by diabetes.

During our conversation, Paul twice refers to advances in eye surgery he has heard about on the radio, but we both know that such developments are out of reach for 99 percent of visually impaired people worldwide. For financial reasons-he lost his medical aid when he was medically boarded nine years ago-Paul has never seen another specialist for an opinion on whether there are any remaining options to help him regain even a little sight. When I ask if he'd consider a visit to the eye clinic at Groote Schuur, he replies that waiting lists are too long. This is likely to be true. Also, he reminds me, it takes hours of waiting before you see a doctor at a government hospital. These obstacles are dishearteningly valid, yet they don't fully explain Paul's evident passivity. Other comments he makes feel more telling.

Firstly, he expresses a reluctance to take further risks, after an unsuccessful surgery:

'... the other thing, I was getting over the shock of losing my sight, at this side; and I'm thinking, this is all I've got, I'm going to hang onto this little bit, because I can sort of see where the light is ...'

Not to risk further interventions is a personal choice. Yet Paul's later comments speak more forcefully of his loss of independence and his fear of being a burden.

Losing one's independence is a painful experience for anybody who undergoes sudden sight loss in their adulthood. I would argue that this is especially the case in late middle age, when patterns of behaviour, and even of being, are firmly entrenched. When I introduce the topic, Paul comments:

\footnotetext{
'That is the problem man, the independence every day, you know, I can't go anywhere ... I don't want to really venture out, because I can't see; if I knock something, I've got a problem with my knee also ... that's why I've got to walk with this crutch, ja, so if I was more sure footed, and ... you know, but like I don't dare go out on my own, man.'
} 
He returns to this subject several times. When I ask him if he has consulted a doctor about his knee, he says he hasn't. He elaborates:

'When you lose your ability to do things, when you lose your independence, you don't want to bother other people to take you there, and you know, things like that. Now they've got to wait for you; you can't ...'

He refuses the possibility of a guide dog:

'Look, I suppose it's someone who's on their own, a guide dog would be okay. Or somebody that ... goes out a lot. But ... if I need to get anywhere, I'll get my son maybe to take me here and there; ... I don't really go out much, you know.'

When I suggest he undertake computer training, he is non-committal. He explains that he doesn't know how he would travel to and from the training.

What help can we expect when without warning, our autonomy is torn away? What are we entitled to hope for? For Paul, the answer seems to be not much. His attitude is likely to some degree simply to be pragmatic. His financial constraints aside, he describes his son and daughter-inlaw, with whom he lives, as hard-working, busy people. Obviously their constant activity is vital for the well-being of the family. However, Paul's attitude also reflects the values of a culture in which independence is sacrosanct, so that people-arguably particularly men-who need help are perceived of as weak or even contemptible. Perhaps this accounts for an unexpressed (possibly inexpressible) feeling of shame that doesn't allow for much acknowledgment of his own vulnerability by asking for help.

To understand Paul's efforts to camouflage and deny his own needs as a response to his impairment entirely of his own making is to misunderstand his position. When I ask him about his employers' and colleagues' attitudes at the time he was forced to take early retirement, he replies:

'... that part was a little bit disappointing, because they weren't very supportive. They ... had me, first, medically boarded, and then discharged, you know? ... But once ... all their paperwork was done, I haven't seen them, you know?'

Joanne: And your colleagues ... were there colleagues you were friendly with?

Paul: Yes, yes, yes, there were quite a few.

Joanne: And have you seen any of them? 
Paul: I suppose I did have one or two of them that sort of ... But on the whole, no, not really. They say they'll come around and they never do. My sons would meet them at the shopping centre somewhere; hey, tell your dad I say, hi, and I'll come and see him, but you never see them.

Joanne: Yes.

Paul: I had a close circle of friends too, I used to visit, just weekends we used to get together, and ... you know, there's a group of us. You don't see them. Well, the one still comes.. the last I've seen him was in October; put it that way.

Joanne: Ja.

Paul: His daughter's birthday, they invited me around to his place. And up until now, in March, I haven't seen them really ... and my one buddy, he rides past here every day, at a certain time, he drives and he'll hoot, toot, toot, toot, he won't pop in ... And then there's a friend that.. two doors away down there ... her husband and I were very, very good friends; he died of cancer, and she's still there, and ... I haven't seen her, just over two years. Just two doors away, and we used to be, you know, very, very ...” ( he trails off)

When I ask Paul why he thinks his sighted friends avoid seeing him, he replies:

'What's that saying? Out of sight, out of mind ... if I go to them, they'll have to fetch me, or they'll have to, you know, lead me around in their homes, because I can't see where.. I don't know their furn[iture] .. here I can operate okay, but I know the layout of the place and what's where, and.. you know. But you go to a strange home, and you've got to be led here, and you need to go to the loo, I can't just go to a loo at somebody's ... because I can't see.'

Conceivably, Paul's own sense of powerlessness and shame affect his conclusions about his friends' lack of loyalty and commitment to their friendship after his sight loss. These feelings can't entirely explain his friends' behaviours, though. Trying to come to terms with a friend becoming disabled is difficult. It demands an openness to the pain of an enormous and possibly ongoing loss. It may take months or even years for that pain to loosen its grip. Maintaining such a friendship also requires a willingness to let go of the previous, sighted version of one's friend and accept that the fundamental changes they have undergone may require new, unfamiliar forms of interaction. Most challenging of all, the onset of disability presents a frightening mirror to the able-bodied person's own potential vulnerability and inevitable physical decline. Unfortunately, Paul's experience of a falling away of friends and acquaintances accompanying sight loss is not particular to him. This has been the experience of many others in a similar position, including me. 


\section{Postscript}

The second time I visit Paul, I learn that with the financial and logistical help of the St Vincent de Paul Society, he was taken to consult another ophthalmologist. Although she advised him that no further intervention is possible, he felt pleased to have had the chance to access her expert opinion. Most of all, he was impressed with her kindness and willingness to explain and answer his questions. In this, he says, she was very different to his previous ophthalmologist, who explained nothing.

\section{CEBISA}

Doctors' ability or hurtful clumsiness in communicating with their patients is a theme that recurs in my discussions.

I meet Cebisa while she was undergoing training in computer skills at Cape Town Society for the Blind. She recalls being diagnosed at Red Cross Childrens' Hospital six years earlier:

'... the way he told me, he said, "okay, listen, now you're totally blind." Then I felt sad, I was like, "I'm not blind at all, why did he tell me that I'm blind?" And then I told myself, "No, my life, it's over." ... I knew there were people who are blind, but I was never exposed to them. So like, no, my life it's over, okay, now what now, what am I going to do?'

This is how Cebisa, aged 14, learned that she had childhood glaucoma, and was facing a very different future than the one she had imagined. She continues:

'And then they told me about ... Athlone School for the Blind. Then I was like, "No, I'm not going to attend that school, because like, I'm not blind! How can I attend a school for blinds, but I'm not?"'

How doctors choose to speak to their patients may have profound effects. Even aside from his apparently unfeeling bluntness, the way Cebisa's doctor presented her diagnosis is problematic. Currently, the misleading and crude binary of sight (equated to light) and blindness (equated to total darkness) dominates the popular understanding of what vision is. It is inaccurate, confusing, and unhelpful for a doctor to express a diagnosis in terms that perpetuate this notion. It seems even less acceptable to do this when the patient is a child.

After undergoing surgery on one eye very soon after her diagnosis, Cebisa stayed at home for the rest of the year. She sank into a depression:

'I didn't want to speak. I would just sleep all day, like sleep, sleep.' 
Luckily, she had support-a precious asset after a tough diagnosis. Her mother encouraged Cebisa and arranged for her to see a social worker. A more nuanced and empathetic discussion allowed Cebisa to gain some clarity:

'... she told me that, now Athlone School for the Blind, is not just for blind people, they're also vision impaired people. And then I asked her, what is vision impaired? Then she told me the people who ... can see a little bit.'

Cebisa settled well at her new school:

'I felt welcomed, like to see people like me at school. And even there were also totally blind people then I saw them, how they are coping, and I told myself then, "no, if they are coping, why will I not be coping?" Then ja, I felt good.'

Cebisa matriculated in 2018 and has applied to study at local tertiary institutions in 2020. The confidence she regained in high school has evidently served her well. She is now a spirited 20 -year old. Her WhatsApp profile picture changes frequently. The photos show her posing in various fashionable outfits, sporting equally various hairstyles. She comes across as assertive yet coolly distant, much like many other young adults I've met, to whom older people seem largely irrelevant.

Cebisa tells me that she's always open about her impairment:

'Everywhere I go, like in a taxi sometimes ... I just tell the driver, no, listen, I'm visually impaired so I can't see, so please tell me where you are.'

I ask Cebisa if anyone has ever needed clarification of what visual impairment means. She responds immediately.

'In Pretoria ... I bumped in[to] a lady, then she asked me, "hey listen, can't you see?" Then I told her, "No, I'm visually impaired, I can't see ..." She was, "Okay, but you have to stay the left side." And then I told her, "Listen, I'm vision impaired." She's like, "What is vision impaired, because both your eyes are open, then you tell me you can't see!" [aggressively] Yoh! That's where I started to panic, because like I must explain what is visual impaired to her now.'

Despite her panic, Cebisa explained her situation successfully, but then encountered another common response-pity:

'Then she was like, “Oh!” She felt pity for me. And then I was like, "No, don't feel sorry for me; I love the way I am. So I'm just sorry I bumped into you, because I didn't see you, and like you are in a hurry.' Then she understood.' 
Joanne: That's great. So you told her, "Don't feel pity for me!"

Cebisa: Mm, because like when they feel pity for me, like, "Oh shame! No, how do you cope?" [whiny tone] and stuff like that, you know.

Joanne: Do you get that a lot?

Cebisa: Mm. Especially when I tell people that, "Listen, I'm visually impaired"; so at shops, in ShopRite, then I ask people, "Where is the toiletry section?" "That side." I said, "Sorry girl, don't say that side! [fiercely] Where? Tell me, because I can't see where you are pointing at, you must show me, or guide me next to that thingy thingy, then I will go there." They say, "Oh sorry, I didn't know that you can't see!" [pitying tone] Then they will guide me to the place that I want.

The pity of strangers can, in one instant, reduce the complex multiple dimensions of an individual's experience to one sad, flat plane. To maintain the sense that their lives are as valuable as anybody else's, it's important for visually impaired people to reject pity whenever it arises. At the same time, we need to be aware that other responses may well feel even worse. According to Cebisa, while she has witnessed some of her visually impaired friends enduring rudeness from others, this hasn't been her own experience. Nevertheless, she has embraced an attitude of resolute daily activism:

\footnotetext{
'That's what I do, every time I see people who pity me, or ... I try to tell them, no, I'm the same like you, nothing more, nothing less, there's nothing special about me, it's just that I can't see far [...] So it's "please don't feel sorry for me!"'
}

When I suggest that although adopting an activist stance is immensely important, it can be tiring, Cebisa responds firmly that she doesn't get tired. She elaborates:

\footnotetext{
'I like people to understand about like vision impaired, or totally blind people, because they can see totally blind people open their eyes, and then they think they can see, but like walking with a cane, and they will think that that person can see ... then I teach them: "Listen, that cane is the indication for you to help that person, or to guide that person if he's going to the wrong direction ... Not for you to skel that person, because they can't see." I like to talk, now ... I don't want anyone to underestimate, or to discriminate ... Me, hayi!'
}

After living with limited sight for six years, Cebisa is well aware of the disheartening ignorance of most South Africans when it comes to visual impairment. Fortunately, she has the energy both of her youth and of her 
disposition to sustain her as she goes about her campaign of educating anybody she encounters who does not understand. Others with different characters and in different situations may find the daily requirement to address this ignorance more difficult.

\section{CONCLUSION}

Life writing exists at the junction of individual, embodied human experience as well as the social terrain on which it plays out, and personal narratives express both of these ontological spheres concurrently. Though they may in themselves be contradictory, elusive, ill-informed or biased, personal narratives speak nevertheless not only of individual personhood, but more broadly of the sociopolitical climate of their time and environment.

In relation to Shima Shahbazi's work on the micro narratives of Iraqi women, Jaume Aurell and Rocio Davis note that researchers who favour the use of personal narratives assert '... their potential to fill a gap in scholarship that considers memoirs by minority writers as narratives of victimhood with political and ideological bias'(2019: 507). They add that life writing has the power to refute dominant narratives, ultimately providing an otherwise missing dimension to the historical record (2019: 507).

Following this logic, one effect of working with the personal narratives of partially sighted South Africans is to counter misleading misconceptions and stereotypes about partial sight and/or blindness, whose endless re-inscription into the culture perpetuates the stigmatisation of visually impaired people. Another is to make evident the erasures those misconceptions are intertwined with, which simultaneously underlie and reinforce the structural barriers that physically, socially and economically exclude visually impaired people, but remain largely hidden.

At the same time as exploring the more obviously social implications of these narratives, attending to their subjective aspects remains important to me as a researcher. In the work referred to above, Shahbazi argues that "we cannot study identities using only hermeneutics; we need phenomenology to bring the body into discussion, because our visibility/invisibility and physical manifestations are crucial in shaping our experience' (2019: 570). While the sensorial adaptations, changed and often changing experience of perception and proprioception arise to a limited extent in the four discussions I present in this paper, this more subjective and individual aspect of partially sighted embodiment is one that I intend to explore further as my project unfolds. Likewise, other subjective invisibilities, for example the paradox of being physically visible yet experiencing an invisibly different way of seeing in return, warrant further exploration. 


\section{WORKS CITED}

Apps, Michelle. 'Access denied: exploring people with disabilities' experiences accessing an erotic life.' MA thesis, Faculty of Social Work: University of Regina, 2016. https://ourspace. uregina.ca/bitstream/handle/10294/7605/Apps_2017_ResearchpracticumSW. pdf? sequence $=1$ \&isAllowed $=y$. Date accessed: 22 June 2020.

Aurell, Jaume and Davis, Rocio. 'History and Autobiography: The Logics of a Convergence.' Life Writing 16:4 (2019) 503-511. DOI: https://doi.org/10.1080/14484528.2019.1648198. Date accessed: 10 May 2020.

Botha, Michelle and Brian Watermeyer. "This Place is Not for Children Like Her": Disability, Ambiguous Belonging and the Claiming of Disadvantage in Post-Apartheid South Africa.' Medical Humanities, Published Online First: 13 November 2018. DOI: https://doi. org/10.1136/medhum-2018-011560. Date accessed: 16 February 2020.

Couser, Thomas. 'Disability and Life Writing.' In: Margaretta Jolly (ed.), The Encyclopaedia of Life Writing. London: Fitzroy Dearborn, 2001, 177-179.

Das, Arpita and Remi Joseph-Salisbury. 'Sexualities and Disabilities.' Graduate Journal of Social Science 12:1 (2016) 6-10. ISSN: 1572-3763. Date accessed: 20 June 2020.

Hall, Matthew. 'Disability, Discourse and Desire: Analyzing Online Talk by People with Disabilities.' Sexualities 21:3 (2017) 379-392. DOI: https://doi.org/10.1177/1363460716688675. Date accessed: 22 May 2020.

European Blind Union. 'Resources' (n.d.). http://www.euroblind.org/publications-andresources/guidelines. Date accessed: 16 November 2020.

McRuer, Robert and Anna Mollow (eds.). Sex and Disability. Durham: Duke University Press, 2012.

Shahbazi, Shima. 'Microhistory Narratives, Alternative Epistemologies and Epistemic Credibility: A Comparative Study of Haifa Zangana's City of Widows and Leilah Nadir's Orange Trees of Baghdad.' Life WritingJournal 16:4 (2019) 567-582. DOI: https://doi.org/ 10.1080/14484528.2019.1633427. Date accessed: 16 June 2020.

\section{ABOUT THE AUTHOR}

Joanne Bloch is a writer and artist living in Cape Town, South Africa. She is a Research Associate of the Wits Institute for Social and Economic Research (WiSER), University of the Witwatersrand, Johannesburg, and a Post-Doctoral Fellow in the English Studies Department, University of the Western Cape, Cape Town. E-mail: joanne@lando.co.za.

The research for this article was funded by the Wits Institute for Social and Economic Research (WiSER).

\section{ETHICAL CONSIDERATIONS}

Two of the participants were happy for the author to use their own names, while in the case of the other two, pseudonyms were used. There are no conflicts of interest in this article. 